Available online at: http://ejournal-balitbang.kkp.go.id/index.php/iaj

\title{
EXPERIMENTAL INFECTIONS OF MILKY HEMOLYMPH DISEASE IN SPINY LOBSTER Panulirus homarus
}

\author{
Sudewi" , Zeny Widiastuti, Bejo Slamet, and Ketut Mahardika \\ Institute for Mariculture Research and Fisheries Extension \\ (Received 2 October 2017; Final revised 15 January 2018; Accepted 15 January 2018)
}

\begin{abstract}
Milky hemolymph disease of spiny lobster (MHD-SL) is categorized as the most destructive disease in farming spiny lobster. Therefore, it is required to investigate the routes of milky disease infection in spiny lobster as a basic knowledge in order to prevent milky disease transmission. The aim of the present study was to perform an experimental infection of milky disease in spiny lobster Panulirus homarus. Experimental infection of milky disease was carried out by several modes of infection which were injection, immersion and per os exposure. Injection of each $0.2 \mathrm{~mL}$ undiluted and diluted hemolymph from the diseased lobster resulted in a cumulative mortality of $100 \%$ at 15 days post-infection (dpi), and $75 \%$ at 16 dpi, respectively. Experimental infection through water immersion caused in a cumulative mortality of $50 \%$ at $7 \mathrm{dpi}$. In contrast, no mortality was observed in per os exposure as well as in control groups. Results of this experimental study provided evidence for horizontal transmission of MHD-SL among P. homarus. Histopathological analysis exhibited that there were masses of Rickettsia-like bacteria (RLB) in the connective tissues of the gill, hepatopancreas, gonad, midgut, and muscle tissues of the affected lobsters. Mass of RLB was not only found in the moribund lobsters but also in the surviving lobsters with milky hemolymph appearance.
\end{abstract}

KEYWORDS: experimental infection; milky hemolymph disease of spiny lobster (MHD-SL); Panulirus homarus; spiny lobster

\section{INTRODUCTION}

A high priority for disease prevention and control in farming of spiny lobster has been set for several diseases including milky hemolymph disease of spiny lobsters (MHD-SL), red body, and black gill disease (Callinan \& Corsin, 2009; Thuy et al., 2010; Vu et al., 2014). Among these diseases, milky disease is reported as the most devastating disease in farming of spiny lobster, which was reported first in Vietnam (Lightner et al., 2008). The annual mortalities ranged from $50 \%$ to $100 \%$ in some regions, at the peak of the disease outbreaks in 2006 and 2007 (Callinan \& Corsin, 2009).

In Indonesia, MHD-SL outbreaks were reported almost year-round in Lombok from 2012 to 2016, and in Pegametan Bay, North Bali in 2016. Morbidity caused by MHD-SL in Lombok reached up to $100 \%$

\footnotetext{
\# Correspondence: Institute for Mariculture Research and Fisheries Extension. Jl. Br. Gondol, Kec. Gerokgak Kab. Buleleng, Kotak Pos 140, Singaraja, Bali 81101, Indonesia.

Phone: + 6236292278

E-mail: dewigrim@ gmail.com
}

and mortality was up to $60 \% 80 \%$ (pers. comm. with Joko Santosa). The worst outbreaks occurred in 2012 when most cultured lobsters in farming areas in Lombok were wiped out by MHD-SL. In Pegametan Bay, mortality of the farmed lobsters in net cages was also reported up to $80 \%$ from July 2016 to January 2017 (unpublished data). The economic losses due to the outbreaks were considerably high.

Considering the significant effects of milky disease in farming of spiny lobster, and limited available information of the disease in Indonesia, this study was conducted to perform an experimental infection of MHD-SL in P. homarus through several modes of infection. Findings in this study provide basic knowledge and understanding on milky disease for developing further practical prevention and sustainable control of the disease.

\section{MATERIALS AND METHODS}

\section{Experimental Infection of Milky Disease}

MHD-SL-infected lobsters used for experimental infection were collected from net cages in Pegametan 
Bay, North Bali during the outbreaks in November 2016, and healthy lobsters were obtained from Jembrana, South Bali. Confirmation for both milky disease infection and health status of the lobsters (free of MHD-SL) was assessed by PCR analysis. DNA was isolated from the muscle tissues using $10 \%$ chelex in TE buffer $\mathrm{pH} 8$, in $1.5 \mathrm{~mL}$ microtubes. DNA was extracted by adding $200-250 \mu \mathrm{L}$ chelex $10 \%$ into the microtubes and homogenized finely; then, 5-7.5 $\mu \mathrm{L}$ pK $(20 \mathrm{mg} / \mathrm{mL})$ was added and incubated at $55^{\circ} \mathrm{C}$ for 2.5 hour. The second incubation was done at $89^{\circ} \mathrm{C}$ for 8 minute. Finally, it was then centrifuged at 13.000 rpm for 5-7.5 min. and the supernatant was collected and stored at $-20^{\circ} \mathrm{C}$ until used for PCR analysis. DNA extraction was completed following Möhlenhoff et al. (2001) with slight modification.

PCR analysis was performed using specific primers for RLB which were $254 \mathrm{~F}$ and $254 \mathrm{R}$ for the expected PCR product (amplicon) size of $254 \mathrm{bp}$. The oligonucleotide sequences of the 254F primer were 5'-CGA-GGA-CCA-GAG-ATG-GAC-CTT-3' and 254R primer were 5'-GCT-CAT-TGT-CAC-CGC-CAT-TGT-3' (OIE Aquatic Animal Disease Cards, 2007; Thuy, 2011; DAFF, 2012; Lasmika, 2015). The reaction mix for PCR contained 2x KAPA 2G Fast Ready Mix, primer 254F $(10 \mu \mathrm{M})$, primer $254 \mathrm{R}(10 \mu \mathrm{M})$, NFW, and DNA template with the total reaction of $10 \mu \mathrm{L}$. DNA amplification was done in an automatic thermal cycler (Personal Thermalcycler, Biometra, 96 well fast). The thermal cycling program consisted of an initial denaturation at $96^{\circ} \mathrm{C}$ for $3 \mathrm{~min}$.; followed by 30 cycles of denaturation at $96^{\circ} \mathrm{C}$ for $15 \mathrm{sec}$., annealing at $65^{\circ} \mathrm{C}$ for $30 \mathrm{sec}$., and extension at $72^{\circ} \mathrm{C}$ for $15 \mathrm{sec}$.; and the last step was a final extension at $72^{\circ} \mathrm{C}$ for $1 \mathrm{~min}$. (modified from Koesharyani et al., 2016). The PCR products were maintained at $4^{\circ} \mathrm{C}$ at the end of the cycling. The products were then separated by electrophoresis in a $1.5 \%$ agarose gel in $1 \mathrm{X}$ TBE buffer (trisborate-EDTA) containing $0.05 \mu \mathrm{L} / \mathrm{mL}$ of red safe DNA stain. The targeted product was measured using a 100bp DNA ladder under a UV-Transilluminator.

The experimental infection study was done for healthy lobster (mean weight $=141.15 \pm 25.85 \mathrm{~g}$ ) in $100 \mathrm{~L}$ tanks. The tested lobsters were assigned to 1 of 6 experimental treatments, four lobsters each: 1) injected with $0.2 \mathrm{~mL}$ undiluted infected hemolymph, 2) injected with 0.2 diluted (1:4) infected hemolymph, 3) immersed in $80 \mathrm{~L}$ sea water administered with 12.5 $\mathrm{mL}$ of undiluted hemolymph, 4) fed frozen $\left(-20^{\circ} \mathrm{C}\right)$ heavily infected $P$. homarus tissue (per os exposure treatment), 5) injected with $0.2 \mathrm{~mL}$ PBS (as the negative control for injection exposure), and 6) fed trash fish (as the negative control for per os exposure and immersion treatment). The infected hemolymph was diluted with sterile PBS. The injection was done in the first abdominal segment using a sterile $1 \mathrm{~mL}$-syringe fitted with a 25-gauge $16 \mathrm{~mm}$ needle. The second addition of the infected hemolymph $(5 \mathrm{~mL})$ in the immersion method was done at day- 6 after the first addition. In the per os exposure treatment, the lobsters were fed heavily infected $P$. homarus tissue from day- 1 to day- 6 with a total of $54.5 \mathrm{~g}$ infected tissue (Table 1). At day-7 afterward, the tested lobsters were fed trash fish due to the limitation of the infected tissue. The diseased lobster used as feed was confirmed for severe infection of MHD-SL by PCR analysis (Figure 1 ), and kept at $-20^{\circ} \mathrm{C}$ until use. Trash fish was used to feed lobsters in other treatments. All lobsters were fed twice daily to satiation at 08:00 and 15:00. Signs of disease, mortality and moribund lobsters were observed and recorded daily until the experiment was terminated (33 days). Percentage of mortality was calculated as the number of lobsters died divided by the initial density. Cumulative mortality is the sum of mortality during the experiment (Hunt et al., 1985). Dead lobsters were frozen for PCR analysis as described above, whereas moribund lobsters were preserved in Davidson's fixative for histopathological examination.

\section{Histopathological Examination}

Both milky disease-free lobsters (control groups) and moribund infected lobsters from the experimental infection study were collected for histopathological examination. Samples of hepatopancreas, muscle, gill, midgut, and gonad were preserved in bouin's fixative for histopathological examination. The samples were then transferred into $70 \%$ alcohol solution before tissue processing. The tissues were placed in a cassette embedding for tissue processing which was done through several steps. First, the tissues were dehydrated by immersing it in graded ethanol (70\% 80\% 90\% 95\% and $100 \%$, and then xylene solution to allow complete penetration of wax into the tissues. Following that, the tissues were embedded in ParaPlast Plus paraffin, sectioned at $5 \mu \mathrm{m}$ thickness, mounted onto microscope slides, and air dried overnight prior staining with haematoxylin eosin (HE) (Nunan et al., 2010). Histopathological examination of the processed tissues was performed using standard light microscope.

\section{Data Analysis}

The data of mortality pattern resulted from the experimental infection was presented in a table and analysed descriptively. The results of the histopathological examination were also shown in a table, and histopathological changes in tissues of the infected lobster were described in figures. 
Table1. The amount ( $\mathrm{g}$ ) of milky diseased P. homarus tissues used to feed the tested lobsters in the per os exposure treatment from day- 1 to day- 6

\begin{tabular}{cc}
\hline Day & Feed $(\mathbf{g})$ \\
\hline 1 & 11 \\
2 & 10 \\
3 & 9 \\
4 & 10 \\
5 & 9 \\
6 & 5.5 \\
\hline Total & 54.5 \\
\hline
\end{tabular}

$\begin{array}{llll}M & 1 & 2 & 3\end{array}$

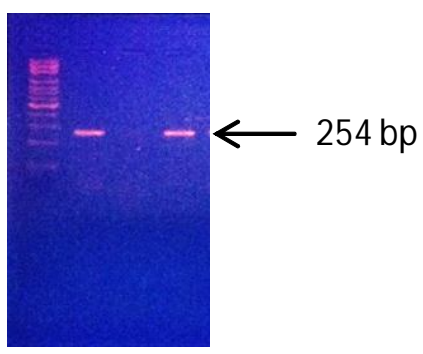

Figure1. Electrophoresis banding patterns of milky diseased and healthy lobsters following PCR using a rickettsial primer set that amplifies a unique 254 bp region within the rickettsial DNA gene. M: 100 bp DNA ladder; lane 1: positive control; lane 2: healthy lobster; lane 3: heavily infected lobster that used as feed and its hemolymph was used for experimental infection.

\section{RESULTS AND DISCUSSION}

\section{Experimental Infection Study of Milky Disease}

All the experimentally infected lobsters showed milky hemolymph and exhibited a similar disease symptom and pattern of mortality in naturally infected lobsters. The mortality pattern of experimentally infected lobsters was found to vary with the method of disease introduction. Mortalities began at four days post-infection (dpi) when the pathogen was administered by intramuscular injection of $0.2 \mathrm{~mL}$ undiluted and diluted hemolymph. A cumulative mortality of $100 \%$ was observed within 15 days in lobsters injected with $0.2 \mathrm{~mL}$ undiluted infected hemolymph, and mortality of $75 \%$ occurred within 16 days in lobsters injected with diluted hemolymph (Table 2). It was clear that the healthy lobster could be infected by MHD-SL by intramuscular injection of $0.2 \mathrm{~mL}$ undiluted and diluted infected hemolymph. This infection was confirmed by PCR analysis (Figure 2). This finding indicated that dilution of hemolymph with sterile PBS at a ratio of $1: 4$ caused in a relatively high mortality $(75 \%$ when compared to undiluted hemolymph which resulted in mortality of $100 \%$ M ortal ity rate $100 \%$ was also obtained in a previous study when lobsters $P$. ornatus were injected with unfiltered hemolymph from the milky diseased lobster. The hemolymph was diluted with saline solution at a ratio of $1: 3$ and injected into healthy lobsters at a dose of $0.1 \mathrm{~mL} / \mathrm{lob}$ ster and $0.3 \mathrm{~mL} / \mathrm{lobster}$ (Hoa et al., 2009).

Furthermore, the present study found that milky disease could be transmitted through water immersion. Lobsters exposed to milky disease by water immersion experienced cumulative mortality of $50 \%$ within seven days post-infection (Table 2). The mortality did not occur after seven days because the addition of the infected hemolymph into the rearing tank was stopped. The additions of the infected hemolymph were only two times, $12.5 \mathrm{~mL}$ into the $80 \mathrm{~L}$ rearing water on day- 1 and $5.0 \mathrm{~mL}$ on day- 6 . The two remaining lobsters were healthy and finally one of the tested lobsters moulted at the end of the ex- 
Table 2. Details of mortality pattern recorded during the experimental infection of milky disease in spiny lobster P. homarus by several modes of infection. The mortality pattern indicated that the experimental infection by injection caused severe mortality than immersion method

\begin{tabular}{|c|c|c|c|c|c|c|c|c|c|c|c|}
\hline \multirow{2}{*}{ Modes of infection } & \multicolumn{6}{|c|}{$\begin{array}{l}\text { Mortality at day post } \\
\text { infection (dpi) }\end{array}$} & \multirow{2}{*}{$\begin{array}{c}\text { Cumulative } \\
\text { mortality } \\
(\%)\end{array}$} & \multicolumn{3}{|c|}{$\begin{array}{l}\text { Experimental } \\
\text { extension (dpi) }\end{array}$} & \multirow{2}{*}{$\begin{array}{l}\text { Total time of } \\
\text { experiment } \\
\text { (days) }\end{array}$} \\
\hline & 0 & 4 & 57 & 710 & 15 & 16 & & 17 & 28 & 33 & \\
\hline Injection of $0.2 \mathrm{~mL}$ undiluted hemolymph $(\mathrm{n}=4)$ & 0 & 2 & $1 * 0$ & 00 & 1 & 0 & 100 & & & & 16 \\
\hline Injection of $0.2 \mathrm{~mL}$ diluted hemolymph $(n=4)($ Tank A) & 0 & 1 & 00 & 00 & 1 & 1 & 75 & $1^{\text {** }}$ & & & 17 \\
\hline Injection of $0.2 \mathrm{~mL}$ diluted hemolymph $(n=4)($ Tank $B)$ & 0 & $1 *$ & 00 & 01 & 0 & 0 & 50 & $2^{* *}$ & & & 17 \\
\hline W ater exposure $(n=4)$ & 0 & 0 & 02 & 20 & 0 & 0 & 50 & 0 & 0 & & 28 \\
\hline Per os exposure $(n=4)($ Tank A) & 0 & 0 & 00 & 00 & 0 & 0 & 0 & & & & 28 \\
\hline Per os exposure $(n=4)$ (Tank B) & 0 & 0 & 00 & 00 & 0 & 0 & 0 & & 1 ** & & 28 \\
\hline Injection of $0.2 \mathrm{~mL}$ sterile PBS (control) $(n=4)$ & 0 & 0 & 00 & 00 & 0 & 0 & 0 & & & $1^{* * *}$ & 33 \\
\hline Fed trash fish (control) $(n=4)$ & 0 & 0 & 00 & 00 & 0 & 0 & 0 & & & & 33 \\
\hline \multicolumn{12}{|c|}{$\begin{array}{l}\text { Note: Dissection for histo pathological examination: } \\
\text { * : Moribund lobster with symptoms of milky disease } \\
\text { * } \quad \text { : The surviving lobster showing milky hemolymph appearance } \\
\text { *** : The control lobster with no signs of milky disease }\end{array}$} \\
\hline
\end{tabular}

periment. PCR analysis showed that the dead lobsters were infected by milky disease although the DNA band was not so clear compared to those infected by intramuscular injection of affected hemolymph (Figure 2).

Transmission of milky disease was also happened in per os exposure treatment. Lobster fed with infected tissue survived until 16 days. However, one lobster exhibited clinical symptom resembling milky hemolymph appearance (Figure 3). This result demonstrated that feeding with infected tissue could affect healthy lobster which was indicated by milky hemolymph appearance. This finding suggests that the natural route of milky disease introduction could occur through feeding infected lobsters. A further observation showed that milky hemolymph appearance decreased when the experiment was extended until day-28 (Figure 3). Although milky hemolymph appearance was lesser, the lobster was confirmed to be affected by milky disease based on PCR analysis (Figure 2). The decrease in milky appearance probably suggested that the lobster could recover from the infection when feeding with infected tissue was terminated. In addition, the concentration of RLB in the lobster's muscle was probably lower than those in hemolymph. Another reason may be that RLB in the muscle had been weakened due to storage in temperature of $-20^{\circ} \mathrm{C}$. Therefore, further study is required

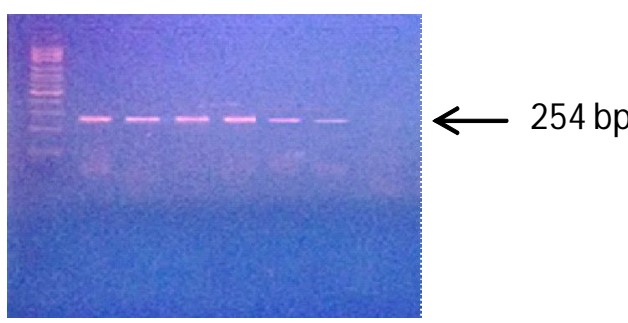

Figure 2. PCR results showed that experimental infection of milky disease by injection of $0.2 \mathrm{~mL}$ undiluted hemolymph (lane 2), $0.2 \mathrm{~mL}$ diluted hemolymph (lane 3 and 4); by water immersion (lane 5) and by per os exposure (lane 6) were successfully transmitted milky disease from the diseased lobsters to the healthy lobsters. In contrast, no DNA band was detected in the control group (lane 7). M: DNA ladder 100 bp marker; lane 1: positive control. DNA was extracted from the muscle tissue of the dead lobsters collected during the experiment. 


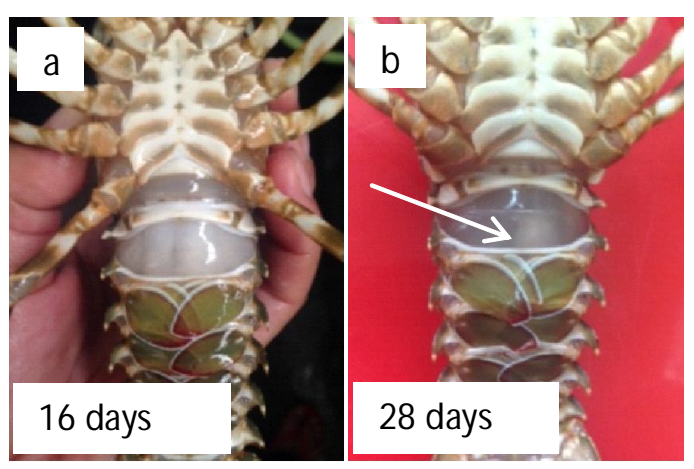

Figure 3. Milky hemolymph appearance in lobster P. homarus fed infected tissues (per os exposure) after 16 days (a), and decreasing of milky hemolymph appearance (white arrow) after 28 days of rearing (b).

to investigate the effects of storage on the pathogenicity of RLB causing MHD-SL.

There was no mortality in the control groups (fed trash fish and injected with sterile PBS). The surviving animals in the control groups appeared healthy and did not reveal any signs of milky disease. Experimental lobsters showed normal feeding and activity until the end of the experiment (33 days) (Table 2) and confirmed free of milky disease by PCR (Figure 2, lane 7).

Milky disease transmission had also been experimented on other decapods crustacean. Intrahaemocoelic injection of 100-300 $\mu \mathrm{L}$ hemolymph from infected European crabs (Carcinus maenas) into healthy individuals caused in mortalities of $100 \%$ within only 24 hours post injection (Eddy et al., 2007). In addition, experimental transmission of RLB from P. monodon to P. vanamei by injecting of RLB-infected frozen $\left(-70^{\circ} \mathrm{C}\right) \mathrm{P}$. monodon tissue homogenate into the SPF P. vannamei resulted in a cumulative mortality of $97 \%$ Contrastingly, per os exposure of frozen RLBinfected $P$. monodon to the SPF P. vannamei resulted in $93 \%$ survival rate at $21 \mathrm{dpi}$ when the experiment was terminated (Nunan et al., 2003b). Then, they concluded that per os exposure of infected P. monodon tissue to SPF P. vannamei did not transmit disease. In the study by Nunan et al. (2003b), the SPF P. vannamei was fed $2.5 \%$ body weight $(4.5 \mathrm{~g}$ of the frozen $\mathrm{P}$. monodon RLB-infected tissue collected during rickettsial disease outbreak in Madagascar). Feeding with infected tissue was done twice a day, for only two days. A similar study by Eddy et al. (2007) also showed that there was neither mortality nor white coloration of hemolymph when the disease-free European crabs fed hepatopancreas from milky diseased crabs for up to eight weeks post-challenge. Their results were contradictory to the present study. Our results showed that milky disease could be transmitted through per os exposure which was confirmed by PCR analysis. Their conclusion should be revised, because the feeding rates examined in their experiment, might not adequate to result in the introduction of the disease.

\section{Histopathological Examinations}

Histopathological analysis showed the presence of masses of RLB in the gill, hepatopancreas, gonad, midgut, and muscle tissues (Table 3 ). Infection of MHD-SL was not only found in the moribund lobster but also in the surviving lobsters that were exhibited milky hemolymph appearance, white or pale coloration of gill and hepatopancreas. In contrast, there was no mass of RLB in the hepatopancreas, gill, gonad, midgut, and muscle of lobster in the control groups (Table 3).

Histopathological examinations confirmed a severe systemic RLB infection in a variety of tissues in the affected P. homarus. RLB fulfilled connective tissue cells and fixed phagocytes, causing enormous hypertrophy in the hepatopancreas, muscle, gill, gonad, and midgut. The infected connective tissue typically appeared to contain baso philic (with $\mathrm{H} \& \mathrm{E}$ ) granular-like masses (rod shape) from small size to large masses (blue *) (Appendix 1, 2, 3).

The histopathological conditions of infected spiny lobsters, shrimp, and crabs were remarkable and mostly identical. A similar disease with similar gross and histopathological lesions particularly in connective tissues had been reported in captive-wild European shore crab (Carcinus maenas) (Eddy et al., 2007) 
Table 3. Histopathological examinations on hepatopancreas, gill, midgut, muscle, and gonad tissues of sub-adult spiny lobster $P$. homarus resulted from experimental infection of milky disease by several modes of infection. D: positive detection (showing mass of RLB); ND: not detected. NA: not available

\begin{tabular}{|c|c|c|c|c|c|}
\hline \multirow{2}{*}{ Modes of infection } & \multicolumn{5}{|c|}{ Histopathological examinations } \\
\hline & Hepatopancreas & Gill & Mid gut & Muscle & Gonad \\
\hline $\begin{array}{l}\text { Injection of } 0.2 \mathrm{~mL} \text { undiluted hemolymph; moribund lobster } \\
\text { Injection of } 0.2 \mathrm{~mL} \text { diluted hemolymph; surviving lobster } \\
\text { with milky hemolymph; }\end{array}$ & $\mathrm{D}$ & NA & $\mathrm{D}$ & $\mathrm{D}$ & $\mathrm{D}(\widehat{\jmath})$ \\
\hline Sample-1 & D & ND & NA & $\mathrm{D}$ & $\mathrm{D}\left(\hat{O}^{\hat{T}}\right)$ \\
\hline Sample-2 & $\mathrm{D}$ & $\mathrm{D}$ & ND & ND & $\mathrm{D}(\hat{0})$ \\
\hline Sample-3 & D & $\mathrm{D}$ & NA & ND & $D(\widehat{\partial})$ \\
\hline Injection of $0.2 \mathrm{~mL}$ diluted hemolymph; moribund lobster & D & ND & ND & ND & $\mathrm{ND}(\hat{\jmath})$ \\
\hline $\begin{array}{l}\text { Per os exposure; surviving lobster with milky hemolymph } \\
\text { appearance }\end{array}$ & ND & NA & NA & ND & $D(p)$ \\
\hline Control & ND & ND & ND & ND & NA \\
\hline
\end{tabular}

and in cultured black tiger shrimp (Penaeus monodon) (Nunan et al., 2003a). The lesions caused by RLB infection of the respective RLB were essentially similar, as shown by sections through the HP and gills (Nunan et al., 2010).

The causative agent of milky disease appeared to be replicated mainly in the fixed phagocytes observed in the hepatopancreas. The early stage of the replication was stated occurred within a large vacuole or in the cytosol of the fixed phagocytes and then released into the surrounding area. Subsequently, the remaining fixed phagocytes were enclosed by large amounts of bacteria comprised within the extracellular space adjoined by the uncommon perforated basement membrane. It was assumed that the bacteria circulate through these perforations to get into the general haemocoel, giving the characteristic milky colour symptomatic of this disease (Eddy et al., 2007).

Results of the histopathological examinations in this study demonstrated that RLB did not only infect the hepatopancreas and gill, but also the muscle, gonad, and midgut. However, in the previous study of rickettsia-like infections in crab, C. maenas showed that there was no evidence of the presence of RLB in mid gut, gonad, and muscle tissues. It was unclear whether the RLB was capable of parasitizing within midgut epithelial cells of the crab (Eddy et al., 2007).

\section{CONCLUSION}

The experimental infection indicated that milky disease could be transmitted horizontally from the diseased lobsters to the healthy lobsters by injec- tion of undiluted and diluted hemolymph of the infected lobsters, by water immersion, as well as per os exposure. Histopathological analysis demonstrated that mass of Rickettsia-like Bacteria (RLB) was detected in the hepatopancreas, gill, midgut, gonad, and muscle tissues of the infected lobsters. The presence of RLB was not only observed in the moribund lobster, but also in the surviving lobsters with milky disease symptoms.

\section{ACKNOWLEDGMNTS}

This study was funded by APBN of Agency for Marine and Fisheries Research and Human Resources, Ministry of Maritime Affairs and Fisheries in 2016. We gratefully thank to the laboratory staff at the Institute for Mariculture Research and Fisheries Extension Gondol, Bali for their help during the study.

\section{REFERENCES}

Callinan, R., \& Corsin, F. (2009). Audit of diseases of farmed spiny lobsters in Vietnam. ACIAR Project SM AR 2008/021.

DAFF. (2012). Milky hemolymph disease of spiny lobster (Panulirus spp.) (Also known as milky hemolymph syndrome (MHS). Aquatic Animal Diseases Significant to Australia: Identification Field Guide 4th Edition. Department of Agriculture, Fisheries and Forestry. Australian Government.

Eddy, F., Powell, A., Gregorey, S., Nunan, L.M., Dayson, P.J., Rowley, A.F., \& Shields, R.J. (2007). A novel bacterial disease of the European shore crab, Carcinus maenas molecular pathology and epidemiology. Microbiology, 153, 2839-2849. 
Hoa, D.T., Cuong, N.T., Dung, N.H., Giang, N.T.T., Ut, P.V., Hue, N.T.N., \& Ha, D.T. (2009). Milky diseasecausing agents in cage cultured lobsters (Panulirus ornatus) in central area of Vietnam. Journal of fisheries science and technology, Special number/2009, p. 9-13.

Hunt, J.H., Lyons, W.G., \& Kennedy, F.S. (1985). Effects of exposure and confinement on spiny lobsters, Panulirus argus, used as attractants in the Florida trap fishery. Fishery Bulletin, 84(1), 69-76.

Lasmika, Ni L.A. (2015). Study on infectious disease in wild and cultured lobsters (Panulirus homarus) in West Nusa Tenggara. M aster Thesis. Pasca Sarjana Sekolah Tinggi Perikanan, Jakarta.

Lightner, D.V., Pantoja, C.P., Redman, R.M., Poulos, B.T., Nguyen, H.D., Do, T.H., \& Nguyen, T.C. (2008). Collaboration on milky disease of net-pen-reared spiny lobsters in Vietnam. OIE Bulletin, 2, 46-47.

Koesharyani, I., Gardenia, L., \& Lasmika, N.L.A. (2016). Molecular detection and cloning for rickettsia-like bacteria of milky hemolymph disease of spiny lobster Panulirus spp. Indonesian Aquaculture Journal, 11(2), 81-86.

Möhlenhoff, P., Lars, M., Anna, A.G., \& Karin, P. (2001). Molecular approach to the characterization of fungal communities: methods for DNA extraction, PCR amplification and DGGE analysis of painted art objects. FEM S M icrobiology Letters, 195(2), 169173.

Nunan, L.M., Poulos, B.T., Redman, R., Le Groumellec, M., \& Lightner, D.V. (2003a). Molecular detection methods developed for a systemic rickettsia-like bacterium (RLB) in Penaeus monodon (Decopoda: Crustacea). Dis. Aquat. Org., 53, 15-23.

Nunan, L.M., Noble, B., Le Groumelle, M., \& Lightner, D.V. (2003b). Experimental infection of Penaeus vannamei by a rickettsia-like bacterium (RLB) originating from P. monodon. Dis. Aquat. Org., 54, 43-48.

Nunan, L.M., Poulos, B.T., Navarro, S., Redman, R.M., \& Lightner, D.V. (2010). Milky hemolymph syndrome (MHS) in spiny lobsters, penaeid shrimp and crabs. Diseases of aquatic organisms, 91(2), 105112.

OIE Aquatic Animal Disease Cards. (2007). Milky hemolymph disease of spiny lobsters (Panulirus spp.).

Thuy, N.T.B., Decamp, O., Visch, S., \& Hanh, N.Q. (2010). Spiny lobster farming in Vietnam and the role of probiotics during production. AQUA Culture Asia Pacific Magazine, November/December 2010, p. 37-39.

Thuy, N.T.T. (2011). NghiêncéumÙtvàið.cðiÃm sinh híccça RLB ß tômhùmBông. Nha Trang University, KhanhHoa.

Vu, N.N., Tung, H., Long, L.T., Leong, H.C., Ngoc, T.B., \& Nguyen, H.T.T. (2014). Rickettsia-like bacteria (RLB) infection and milky hemolymph symptoms (M HS) in spiny lobster cultured in Vietnam. A thesis submitted to The School of Biotechnology, International University in Partial Fulfilment of the Requirements for the Degree of B.S. in Biotechnology. Vietnam National University, Ho Chi Minh City. Vietnam, p. 11-15. 
Appendix 1. Histopathological changes in tissues of sub-adult spiny lobster P. homarus affected by milky hemolymph disease of spiny lobster (MHD-SL). (A) normal hepatopancreatic tubules in cross section showing fixed phagocytes (ff) surrounding an arteriole (black arrow) in the hemal sinus (hs). $b m=$ basement membrane, $r c=R$-cell, $h=$ free haemocytes, $\mathrm{L}=$ lumen of tubules. Scale bar, $30 \mu \mathrm{m}$, haematoxylin/eosin stained; (B) cross-sectioned hepatopancreatic tubules of a naturally infected lobster revealing the necrotic tubular structure (blue arrow), and darkly H\&E stained granular-like masses of Rickettsia-like Bacteria (blue *) that are prominent in an arteriole in the haemal sinus. Scale bar $=30 \mu \mathrm{m}$; (C) hepatopancreatic tubules of an experimentally infected lobster in cross section showed the same necrotic tubular structure and mass of RLB (blue *) as the naturally infected lobsters; (D) high magnification of mass of RLB (blue *) in the hemal sinus of the hepatopancreatic tubule that appeared rod in shape, $H \& E$ stained

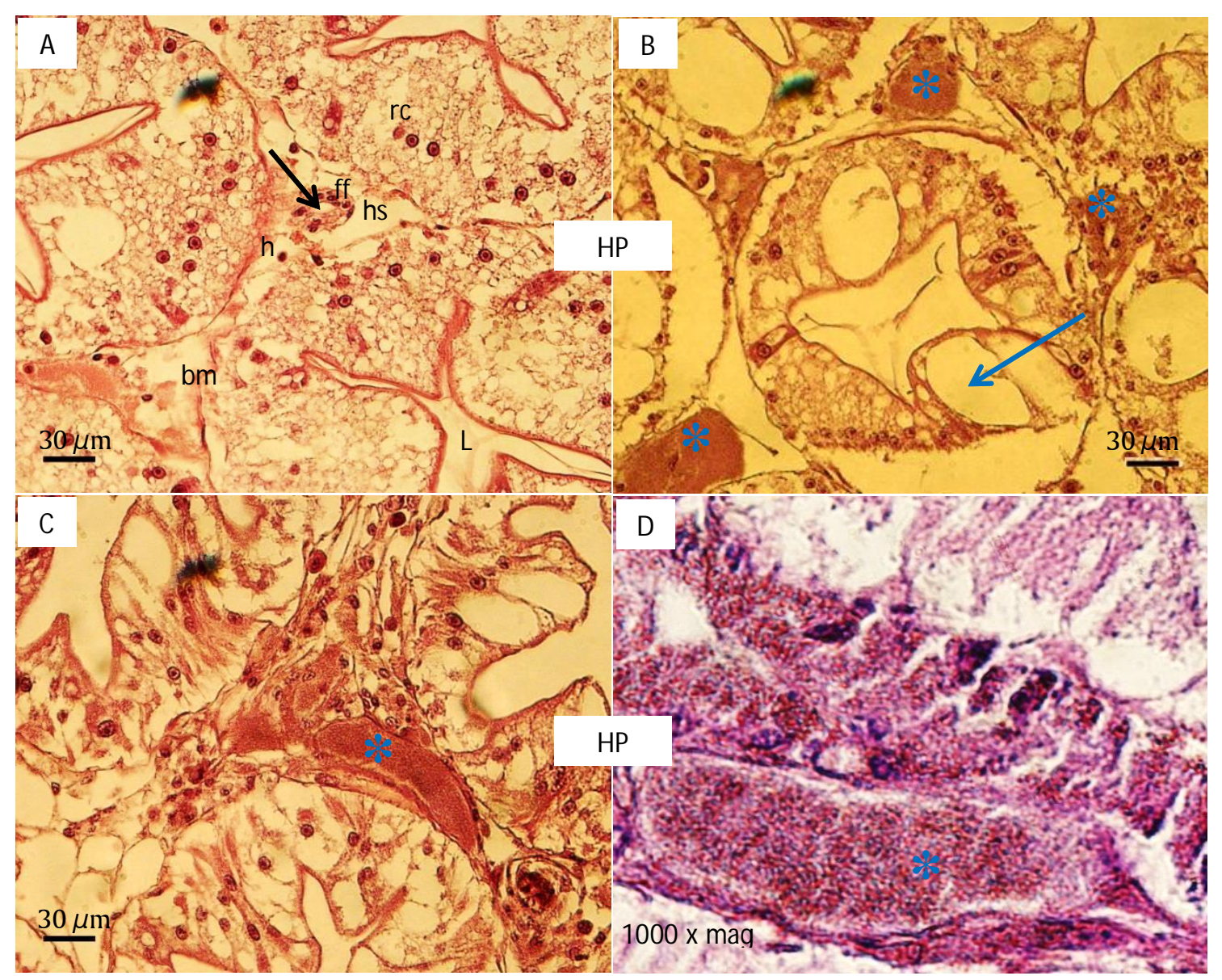


Appendix 2. Histopathological changes in tissues of sub-adult spiny lobster $\mathrm{P}$. homarus affected by milky hemolymph disease of spiny lobster (MHD-SL). (A) longitudinal section of normal skeletal muscle (ms) with the hemal sinus (hs) passing longitudinally across the section, and fixed phagocytes (ff). Scale bar $=30 \mu \mathrm{m}$; (B) milky disease infected skeletal muscle displaying heavy infestation of RLB (blue *). Scale bar $=30 \mu \mathrm{m}$; (C) the normal structure of the gill $(G)$ in cross section with spongy connective tissue (con), gill lamella (lam), and empty hemal sinus (hs). Scale bar $=100 \mu \mathrm{m}$; (D) longitudinal sections through the gills with MHD-SL. Large amounts of RLB appeared in granular-like masses (") fulfilling in the hemal sinus. H\&E stain, scale bar $=60 \mu \mathrm{m}$

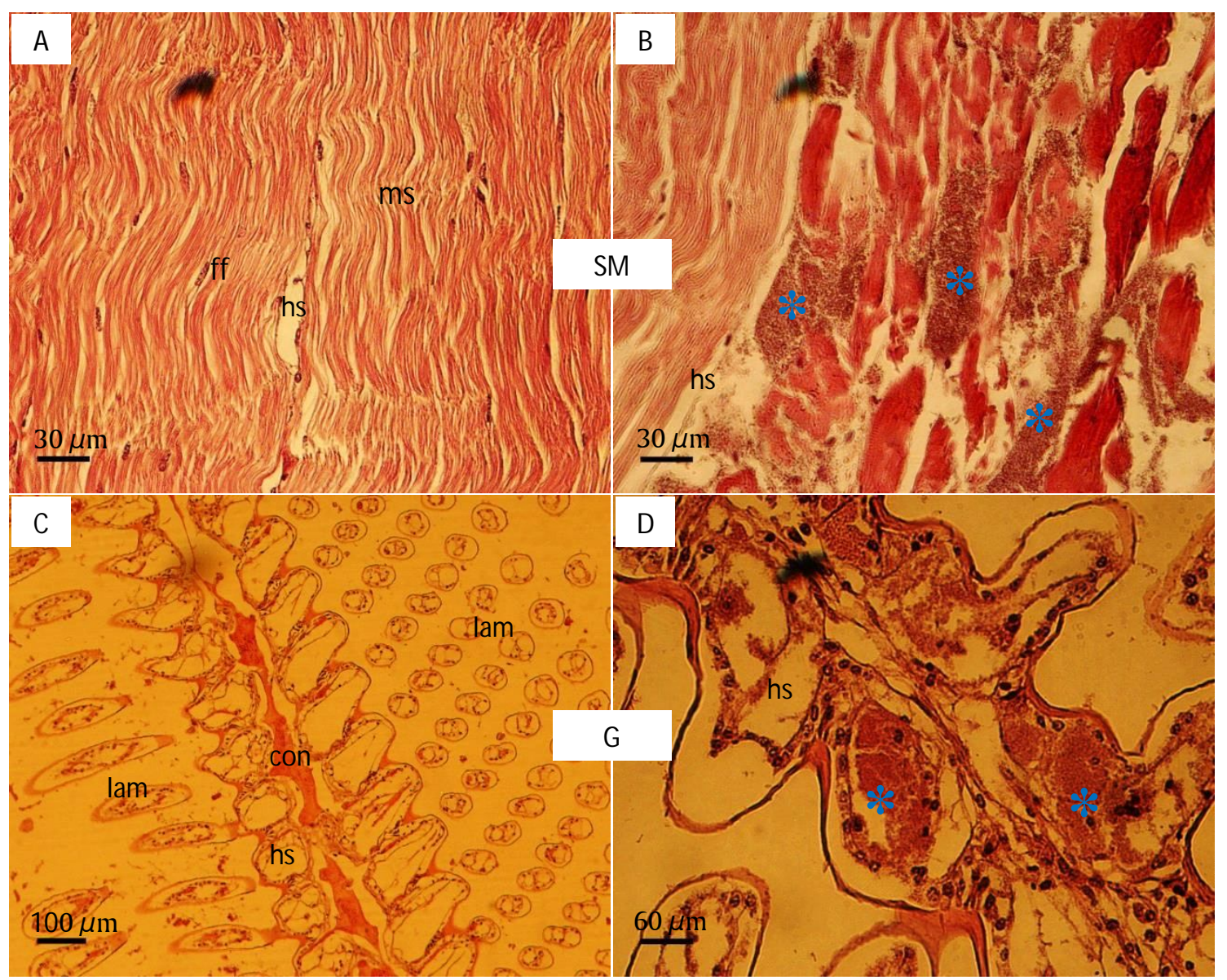


Appendix 3. Histopathological changes in tissues of sub-adult spiny lobster P. homarus affected by milky hemolymph disease of spiny lobster (MHD-SL). (A) the normal ejaculatory duct of male gonad exhibiting epithelial cells (ec), brush border (bb) skeletal muscle fibre (ms) and fibrous connective tissue (fcon). Scale bar $=100 \mu \mathrm{m}$; (B) milky diseased ejaculatory duct indicated by darkly H\&E stained RLB (*) interspersed among fibrous connective tissue. Scale bar $=30 \mu \mathrm{m}$; (C) normal midgut (MG) exhibiting columnar epithelial cells (ec) with brush border (bb) supported on a basement membrane $(\mathrm{m})$ overlying small muscle fibrils (m) and fibrous connective tissue (fcon). Brush border located at the apical end of the epithelial cells. $\mathrm{L}=$ lumen. Scale bar $=30 \mu \mathrm{m}$; (D) milky disease affected midgut indicated by darkly H\&E stained granular-like masses $(*)$ interspersed among muscle fibrils. Scale bar $=30 \mu \mathrm{m}$.

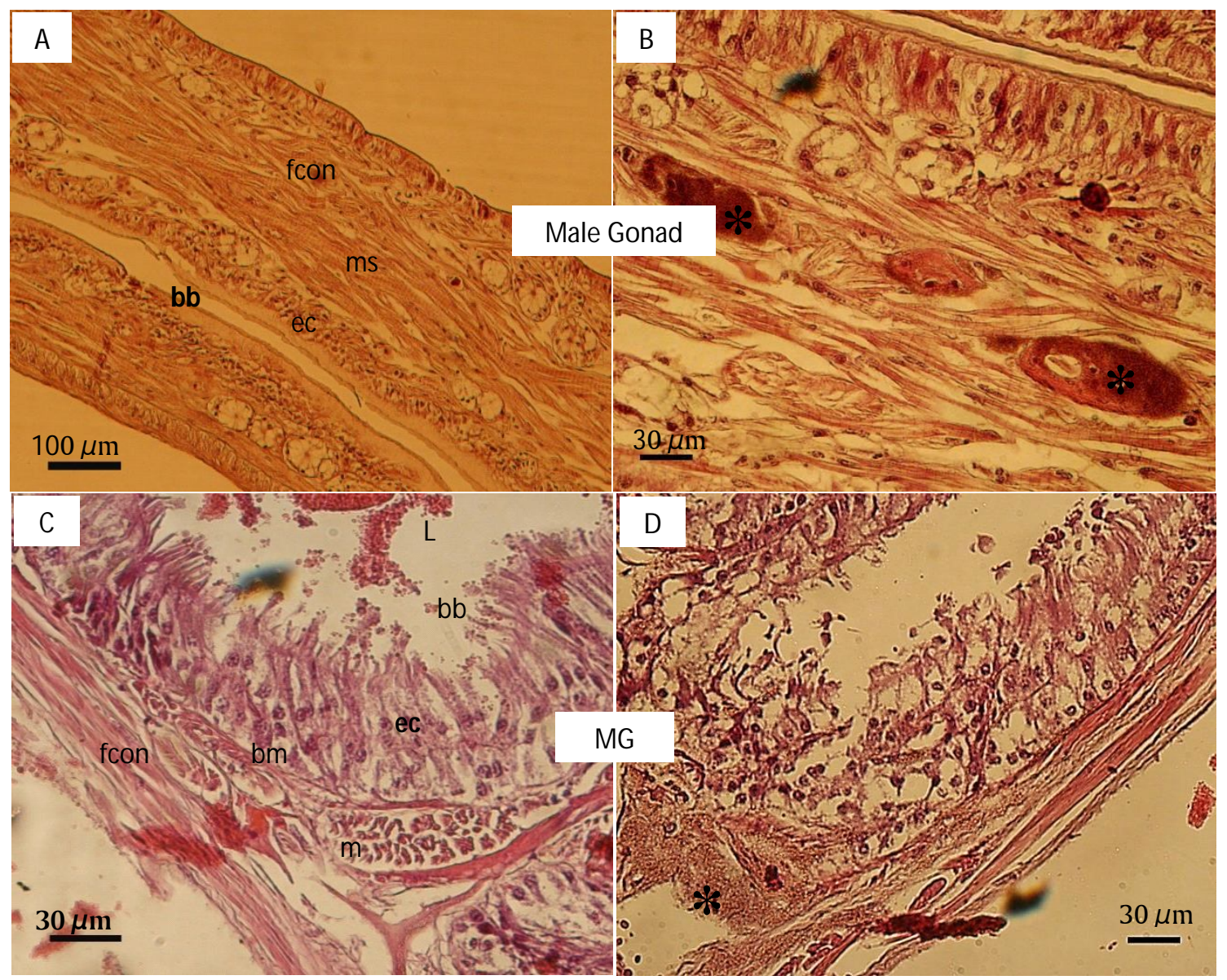

